\title{
Comparison of HLA-G and MMP transcription in human tumor cell lines
}

\author{
K. POLAKOVA ${ }^{1, *}$, E. BANDZUCHOVA ${ }^{2}$ \\ ${ }^{1}$ Cancer Research Institute, Biomedical Research Center, Slovak Academy of Sciences, Bratislava, Slovakia; ${ }^{2}$ National Transplantation \\ Organisation, Bratislava, Slovakia \\ *Correspondence: exompola@savba.sk
}

Received April 9, 2018 / Accepted May 30, 2018

\begin{abstract}
HLA-G antigens and matrix metalloproteinases (MMPs) expressed in various tumors are involved in tumor growth and metastasis. In this study, we investigated if correlation between HLA-G and MMP expression exists in different cell lines. We examined MMP transcription in two choriocarcinoma cell lines: JEG-3 (HLA-G positive) and JAR (HLA-G negative). We discovered that both cell lines express a similar panel of MMPs; except for MMP12. Transcript MMP12 was exclusively detected in HLA-G expressing JEG-3 cells but not in HLA-G deficient JAR cells. We observed HLA-G expression but no MMP12 transcription following 5-aza-2'-deoxycytidine (AZA) treatment of JAR cells. We then investigated HLA-G and MMP transcription in several human leukaemia cell lines. Leukaemia cells (lacking HLA-G expression) were converted to their HLA-G positive counterparts by AZA-treatment or by HLA-G transfection. It was found no correlation between HLA-G and MMP transcription in any examined leukaemia cell lines. The up-regulation of some MMPs and tissue inhibitors of matrix metalloproteinases (TIMPs) was observed following AZA-treatment.
\end{abstract}

Key words: HLA-G, matrix metalloproteinase, DNA hypomethylation, RT-PCR

HLA-G molecules are human non-classic major histocompatibility class I antigens characterized by restricted tissue distribution, limited polymorphism, alternative splicing and immunosuppressive properties [1-4]. HLA-G is primarily expressed in extravillous cytotrophoblasts [5-7], but ectopic expression of HLA-G antigens has been observed in various pathological conditions, including tumors, autoimmune diseases, transplantation and viral infections [8-13]. Due to alternative splicing of primary transcript, there are four membrane-bound (HLA-G1,-G2,-G3, and -G4) and three soluble (HLA-G5, -G6 and -G7) isoforms produced. Moreover, soluble HLA-G molecules are generated from membrane-bound molecules by cleavage with metalloproteinases [14-16]. Increased HLA-G expression was observed in many types of malignancies and association between HLA-G and tumor invasiveness and metastasis was confirmed. For example, HLA-G expression was frequently detected in the most aggressive type of ovarian cancer [17-20].

Matrix metalloproteinases (MMPs) are a large family of zinc-containing endopeptidases which play an important role in degradation of the extracellular matrix (ECM) and in tissue remodeling $[21,22]$. Currently, there are 23 MMPs identified in humans. On the basis of substrate specificity and structure, MMPs can be classified into collagenases (MMP-1, -8, -13), gelatinases (MMP-2, -9), metalloelastases (MMP-12), stromelysins (MMP-3, -10, -11), matrilysins (MMP-7, -26), enamelysins (MMP-20), membrane-types (MMP-14, -15, -16, -17, -24, -25), and others (MMP-19, -21, $-23,-27,-28)$.

The basic structure of all MMPs is very similar and consists of the following domains: N-terminal signal peptide (directs MMPs to the secretory or plasma membrane pathway), pro-peptide (keeps enzyme in inactive state by interaction with zinc), catalytic domain (contains zinc ion binding motif), hinge region (links the catalytic and C-terminal domain) and the C-terminal hemopexin-like domain (determines the substrate specificity of the enzyme and interacts with inhibitors).

An additional transmembrane anchor domain is found in the membrane-type MMPs (MT-MMPs). Both secreted and membrane-bound MMPs are produced in zymogen form 
that can be subsequently activated by proteolytic enzymes. Under normal physiological conditions, the MMP transcription is tightly regulated and the MMP molecules are generally expressed in very low amounts. MMPs are secreted by many cells including fibroblasts, vascular smooth muscle cells-and leukocytes and their expression is regulated by hormones, cytokines-and growth factors. Their enzymatic activity can also be inhibited by specific proteins called tissue inhibitors of matrix metalloproteinases (TIMPs). MMPs serve as effectors in physiological processes such as embryo implantation, morphogenesis, angiogenesis and tissue remodeling in response to injury. MMPs are commonly over-expressed in various types of tumors and play a significant role in tumor invasion and metastasis [23-26].

Recently, strong association between HLA-G and MMP15 expression has been demonstrated in ovarian cancer cells. HLA-G induction in ovarian cell line (HO-8910) elicited up-regulation of MMP15 which resulted in increased cell migration in vitro and tumor metastasis in nude mice. The relationship between HLA-G and MMP15 expression was also observed in patient samples isolated from ovarian cancer $[18,19]$. The main goal of this work, therefore, is to establish correlation between HLA-G and MMP transcription in other tumor cell lines.

\section{Materials and methods}

Cell lines and treatment. The following human cell lines were used: choriocarcinoma cell lines JEG-3 (expressing HLA-G) and JAR (HLA-G deficient) and leukemia cell lines lacking HLA-G (MT1, JURKAT, RAJI, U937, JY, .221 and K562). All cell lines were obtained from the cell collection of the Cancer Research Institute, BMC, SAS, in Bratislava. Choriocarcinoma cell lines were cultured in MEM medium and leukemia cells were grown in RPMI 1640. Both MEM and RPMI 1640 media were supplemented with $2 \mathrm{mM}$ glutamine, $200 \mu \mathrm{g} / \mathrm{ml}$ gentamicin, $0.125 \mu \mathrm{g} / \mathrm{ml}$ amphotericin $\mathrm{B}$ and $10 \%$ heat-inactivated fetal bovine serum.

HLA-G negative cell lines following treatment with DNA hypomethylation agent 5-aza-2'-deoxycytidine (AZA) were converted to their HLA-G positive counterparts. AZA-treatment of JAR and leukemia cell lines was carried out with $100 \mu \mathrm{M}$ 5-aza-2' -deoxycytidine (Sigma) for 3 days [27].

Herein, we also used transfectants expressing HLA-G: K562-G1 and K562-G2 which were kindly provided by Dr. E. Weiss (Munich, Germany) and 221-G1 was obtained from Dr. G. Frumento (Genoa, Italy).

Table 1. Primers for sqRT-PCR analysis of HLA-G.

\begin{tabular}{ll}
\hline Name & Sequence \\
\hline G.257-F & 5'-GGAAGAGGAGACACGGAACA-3 \\
G.1004-R & 5'-CCTTTTCAATCTGAGCTCTTCTTT-3' \\
GAPDH-F & 5'-CATGGGTGTGAACCATGAGAA-3 \\
GAPDH-R & 5'-GGTCATGAGTCCTTCCACGAT-3 \\
\hline
\end{tabular}

RNA isolation and reverse transcription. Total RNA was extracted from cells using Trizol reagent (Life Technologies, USA) according to the manufacturer's instructions. cDNA was prepared by reverse-transcription (RT) as described previously [28]. Briefly, reverse transcription was performed with $2 \mu \mathrm{g}$ of total RNA in $40 \mu \mathrm{l}$ reaction volume using MultiScribe reverse transcriptase and random hexamers (Applied Biosystems, USA). Samples were incubated at temperatures: $25^{\circ} \mathrm{C}(10 \mathrm{~min})$ and $42^{\circ} \mathrm{C}(60 \mathrm{~min})$, and the reaction was then terminated by heating at $95^{\circ} \mathrm{C}$ for $5 \mathrm{~min}$.

Semiquantitative RT-PCR. Semiquantitative RT-PCR (sqRT-PCR) for HLA-G, MMPs and TIMPs was performed using AmpliTaq Gold DNA polymerase (Applied Biosystems, USA) and PCR reactions were carried out on the C1000 Touch thermal cycler (Bio-Rad, USA). Ubiquitously expressed gene glyceraldehyde-3-phosphate dehydrogenase $(\mathrm{GAPDH})$ was used as the internal control. PCR products were visualized by UV light after electrophoresis in $2 \%$ agarose gels stained with GelRed (Biotium, USA).

SqRT-PCR analysis of HLA-G was accomplished with pan HLA-G primers (G.257-F, G.1004-R) as described in Table 1. [29]. The PCR began with incubation at $95^{\circ} \mathrm{C}$ for $15 \mathrm{~min}$, followed by PCR cycles of $1 \mathrm{~min}$ at $94^{\circ} \mathrm{C}, 1.5 \mathrm{~min}$ at $62^{\circ} \mathrm{C}$, $2 \mathrm{~min}$ at $72^{\circ} \mathrm{C}$ and final extension for $7 \mathrm{~min}$ at $72^{\circ} \mathrm{C}$. The number of PCR cycles was determined experimentally: 37 cycles for HLA-G and 25 cycles for GAPDH.

SqRT-PCR conditions for MMP and TIMP analyses were set as follows: $15 \mathrm{~min}$ at $95^{\circ} \mathrm{C}$ for DNA polymerase activation, denaturation at $94^{\circ} \mathrm{C}$ for $30 \mathrm{sec}$, annealing at $57-68^{\circ} \mathrm{C}$ for $30 \mathrm{sec}$, extension at $72^{\circ} \mathrm{C}$ for $40 \mathrm{sec}$ and final extension at $72^{\circ} \mathrm{C}$ for $7 \mathrm{~min}$. PCR product accumulation was measured during the exponential phase and the number of PCR cycles was determined experimentally (34-39 cycles). All primer sequences, annealing temperatures and PCR product sizes are listed in Table $2[18,30-34]$. The asterisks indicate alternative sets of primers used in MMP analysis (Table 2, Figure 2).

Quantitative RT-PCR analysis. Quantitative RT-PCR (qRT-PCR) reactions were performed using the ABI Prism 7000 Sequence Detection System in accordance with the recommendations of the manufacturer (Applied Biosystems, USA). A reaction mixture of $25 \mu$ contained the TaqMan Universal PCR Master Mix, $200 \mathrm{nM}$ of specific primers, $150 \mathrm{nM}$ of specific TaqMan probe and cDNA prepared from $25 \mathrm{ng}$ of total RNA. The thermal cycling conditions included initial activation of DNA polymerase for $10 \mathrm{~min}$ at $95^{\circ} \mathrm{C}$, followed by 40 cycles at $95^{\circ} \mathrm{C}$ for $15 \mathrm{sec}$ and $60^{\circ} \mathrm{C}$ for $1 \mathrm{~min}$. The HLA-G specific probes and primers (Table 3 ) were selected to amplify all alternative forms of HLA-G transcripts [30]. The glyceraldehyde-3-phosphate dehydrogenase (GAPDH) specific probe and primers were used as endogenous control. Comparative cycle threshold method $\left(2^{-\triangle \Delta C T}\right)$ was used to calculate the changes in gene expression of the individual samples relative to the control JEG-3 (assigned a value of 1). Finally, cycle threshold (CT) values were determined by automated threshold analysis with ABI 
Prism software, and the real-time PCR efficiencies of target gene amplification and endogenous control gene amplification were approximately equal.

\section{Results}

Expression of HLA-G transcripts in cells treated with 5-aza-2'-deoxycytidine and in HLA-G transfectants. The main goal of this work was to investigate if HLA-G induction in originally HLA-G deficient cell lines up-regulates some matrix metalloproteinases (MMPs). For this purpose, AZA-treatment was used to prepare from HLA-G deficient cell lines (JAR, MT1, JURKAT, RAJI, U937, JY, .221 and K562) their HLA-G expressing counterparts (JAR+AZA, MT1+AZA, JURKAT+AZA, RAJI+AZA, U937+AZA, $\mathrm{JY}+\mathrm{AZA}, .221+\mathrm{AZA}$ and K562+AZA). HLA-G mRNA expression was analyzed by qRT-PCR; where HLA-G mRNA levels in cell lines were compared to JEG-3 cells (assigned a value of 1). We demonstrated that HLA-G transcription was induced in all AZA-treated cell lines; the highest level of HLA-G mRNA was observed in choriocarcinoma cells $\mathrm{JAR}+\mathrm{AZA}$ and in leukemia cells $\mathrm{MT} 1+\mathrm{AZA}, \mathrm{JY}+\mathrm{AZA}$ and 221+AZA (Figure 1, panel A). qRT-PCR confirmed HLA-G transcription in transfectants 221-G1, K562-G1 and K562-G2 (Figure 1, panel B); with the highest HLA-G mRNA level detected in 221-G1 cells.

Analysis of MMP transcripts in choriocarcinoma cell lines JEG-3 and JAR. Transcription of matrix metalloproteinases (MMPs) in choriocarcinoma cell lines JEG-3 (HLA-G positive) and JAR (HLA-G negative) was investigated by sqRT-PCR. Figure 2 shows that examined MMP expression was almost the same in both cell lines; except for metalloproteinase MMP12. Transcript of MMP12 was detected only in HLA-G positive cells JEG-3 and not in the JAR HLA-G deficient cell line. Because MMP12 transcript was present only in HLA-G expressing JEG-3 cells but not in HLA-G

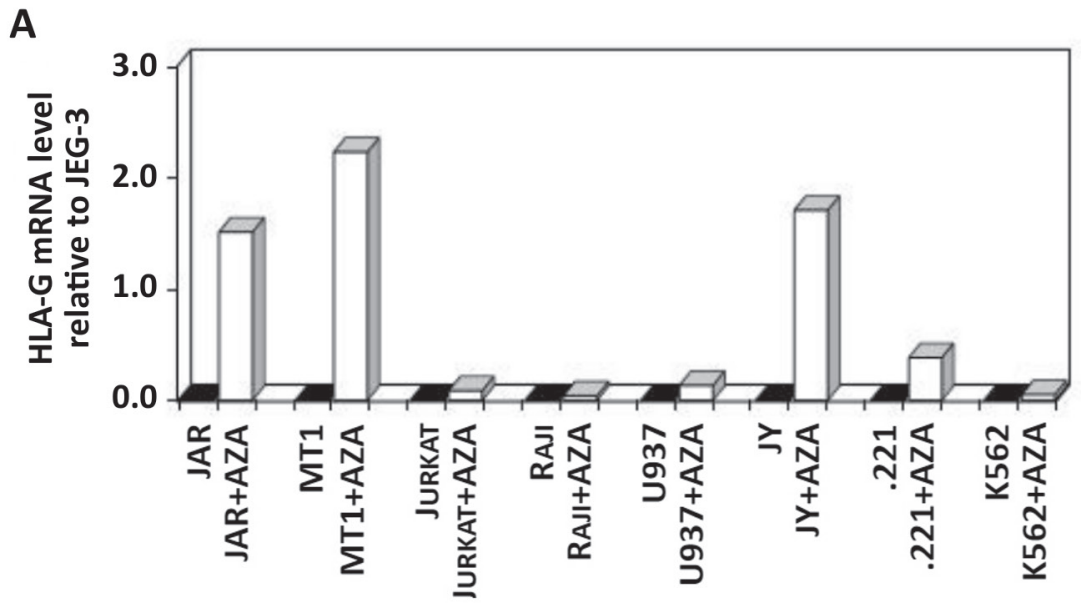

B

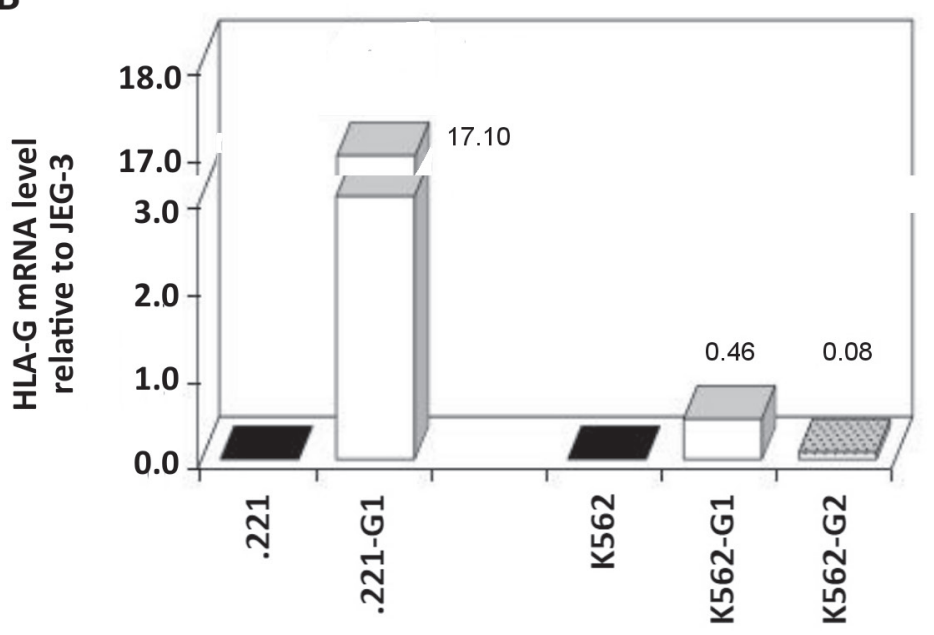

Figure 1. HLA-G expression in cells treated with 5-aza-2'-deoxycytidine and in HLA-G transfectants. Expression of HLA-G mRNA was analyzed by $q$ RT-PCR. HLA-G negative cell lines were modified to the HLA-G positive counterparts by treatment with DNA demethylation agent 5-aza-2'deoxycytidine (AZA) (panel A) or by HLA-G transfection (panel B). HLA-G mRNA levels in cell lines were compared to JEG-3 cells (assigned a value of 1). 
Table 2. Primers used for detection of MMPs and TIMPs by sqRT-PCR.

\begin{tabular}{|c|c|c|c|c|c|c|c|}
\hline Gene & Accession no. & $\begin{array}{l}\text { Annealing } \\
\text { temp. }\left({ }^{\circ} \mathrm{C}\right)\end{array}$ & $\begin{array}{c}\text { cDNA } \\
\text { size (bp) }\end{array}$ & $\begin{array}{c}\text { Genomic } \\
\text { DNA size (bp) }\end{array}$ & References & Forward primer & Reverse primer \\
\hline MMP1 & NM_002421 & 58 & 460 & 2276 & $\begin{array}{l}\text { Hunakova } \\
\text { et al. } 2009\end{array}$ & CAGAGATGAAGTCCGGTTTTTC & CAGGAAAACACCTTCTTTGGA \\
\hline MMP2 & NM_004530 & 60 & 474 & 9662 & $\begin{array}{l}\text { Lin } \\
\text { et al. } 2013\end{array}$ & GGCCCTGTCACTCCTGAGAT & GGCATCCAGGTTATGGGGGA \\
\hline MMP3 & NM_002422 & 58 & 506 & 2309 & $\begin{array}{l}\text { Hunakova } \\
\text { et al. } 2009\end{array}$ & GTTTGTTAGGAGAAAGGACAGTGG & CATGAGCAGCAACGAGAAATAA \\
\hline $\mathrm{MMP}^{*}$ & NM_002422 & 57 & 205 & 1276 & $\begin{array}{l}\text { Kohrman } \\
\text { et al. } 2009\end{array}$ & GGCTTTCCCAAGCAAATAGC & GTGCCCATATTGTGCCTTCT \\
\hline MMP7 & NM_002423 & 58 & 307 & 3000 & $\begin{array}{l}\text { Hunakova } \\
\text { et al. } 2009\end{array}$ & GAGGCATGAGTGAGCTACAGTG & CGATCCACTGTAATATGCGGTA \\
\hline MMP8 & NM_002424 & 62 & 502 & 2658 & $\begin{array}{l}\text { Lin } \\
\text { et al. } 2013\end{array}$ & TCAAGCAACCCTATCCAACC & CTTGCTGGAAAACTGCATCA \\
\hline $\mathrm{MMP}^{*}$ & NM_002424 & 57 & 154 & 852 & $\begin{array}{l}\text { Kohrman } \\
\text { et al. } 2009\end{array}$ & TCTGCAAGGTTATCCCAAGG & ACCTGGCTCCATGAATTGTC \\
\hline MMP9 & NM_004994 & 58 & 187 & 576 & $\begin{array}{l}\text { Hunakova } \\
\text { et al. } 2009\end{array}$ & ATCTTCCAAGGCCAATCCTACT & CCAGGAAAGTGAAGGGGAAG \\
\hline MMP10 & NM_002425 & 60 & 380 & 4260 & $\begin{array}{l}\text { Lin } \\
\text { et al. } 2013\end{array}$ & GTCCTTCGATGCCATCAGCA & CTTGCTCCATGGACTGGCTA \\
\hline MMP10* & NM_002425 & 55 & 819 & 4199 & $\begin{array}{l}\text { Kohrman } \\
\text { et al. } 2009\end{array}$ & CCAGTCTGCTCTGCCTATCC & CATCTCAGATCCCGAAGGAA \\
\hline MMP12 & NM_002426 & 58 & 367 & 3002 & $\begin{array}{l}\text { Lin } \\
\text { et al. } 2013\end{array}$ & CCACTGCTTCTGGAGCTCTT & GCGTAGTCAACATCCTCACG \\
\hline MMP13 & NM_002427 & 62 & 490 & 5383 & $\begin{array}{l}\text { Lin } \\
\text { et al. } 2013\end{array}$ & GACTTCACGATG GCATTGCTG & GCATCAACCTGCTGAGGATGC \\
\hline MMP14 & NM_004995 & 58 & 228 & 697 & $\begin{array}{l}\text { Hunakova } \\
\text { et al. } 2009\end{array}$ & GCAAATTCGTCTTCTTCAAAGG & TGTTCTTGGGGTACTCGCTATC \\
\hline MMP15 & NM_002428 & 60 & 474 & 828 & $\begin{array}{l}\text { Lin } \\
\text { et al. } 2013\end{array}$ & GCATCCAGAACTACACGGAG & TACCGTAGAGCTGCTGGATG \\
\hline MMP16 & NM_005941 & 58 & 383 & 18886 & $\begin{array}{l}\text { Lin } \\
\text { et al. } 2013\end{array}$ & GTACCTGACCAGACAAGAG & AGTGTCCATGGCTCATCTGA \\
\hline MMP17 & NM_016155 & 68 & 313 & 1178 & $\begin{array}{l}\text { Host } \\
\text { et al. } 2012\end{array}$ & AAGGAGACAGGTACTGGGTGTTC & TCGCCATCCAGCACTTTCCAGTA \\
\hline MMP19 & NM_002429 & 61 & 397 & 1155 & $\begin{array}{l}\text { Lin } \\
\text { et al. } 2013\end{array}$ & CAGGCTCTCTATGGCAAGAA & GAGCTGCATCCAGGTTAGGT \\
\hline MMP20 & NM_004771 & 61 & 374 & 6556 & $\begin{array}{l}\text { Lin } \\
\text { et al. } 2013\end{array}$ & GACCAGACCACAATGAACGT & GTCCACTTCTCAGGATTGTC \\
\hline MMP20* & NM_004771 & 57 & 169 & 975 & $\begin{array}{l}\text { Kohrman } \\
\text { et al. } 2009\end{array}$ & CGACAATGCTGAGAAGTGGA & ATCTTTGGGGAGGTGGAATC \\
\hline TIMP1 & NM_003254 & 60 & 145 & 1544 & $\begin{array}{c}\text { Asano } \\
\text { et al. } 2008\end{array}$ & TTCTGGCATCCTGTTGTTGCTG & GGTGGTCTGGTTGACTTCTGGTGT \\
\hline TIMP2 & NM_003255 & 60 & 156 & 1813 & $\begin{array}{c}\text { Asano } \\
\text { et al. } 2008\end{array}$ & TGGGACACCCTGAGCACCAC & GTTGATGTTCTTCTCTGTGACCCAGTC \\
\hline TIMP3 & NM_000362 & 60 & 151 & 1192 & $\begin{array}{c}\text { Asano } \\
\text { et al. } 2008\end{array}$ & GAACTATCGGTATCACCTGGGTTGTAAC & GATGCAGGCGTAGTGTTTGGACT \\
\hline TIMP4 & NM_003256 & 60 & 149 & 763 & $\begin{array}{c}\text { Asano } \\
\text { et al. } 2008\end{array}$ & CTGTGGCTGCCAAATCACCAC & AGGTGCCGTCAACATGCTTCAT \\
\hline
\end{tabular}

lacking cells JAR, we then investigated-if HLA-G induction in the originally negative JAR cell line triggers transcription of metalloproteinase MMP12. The induction of HLA-G expression in JAR cells was achieved by treatment with DNA demethylation agent 5-aza-2'-deoxycytidine (AZA). MMP expression in HLA-G negative JAR cells and in HLA-G positive JAR+AZA cells was investigated by sqRT-PCR, with JEG-3 cells as the positive HLA-G control. Figure 2 shows that MMP12 transcript was absent in both HLA-G negative JAR cells and HLA-G-expressing JAR+AZA cells. These data confirmed that HLA-G expression did not affect MMP12 transcription in the JAR choriocarcinoma cell line.

Analysis of HLA-G and MMP expression in leukemia cell lines treated with 5-aza-2'-deoxycytidine. Although human leukemia cell lines do not express HLA-G antigen, HLA-G transcription can be induced in many of them by 5 -aza-2' -deoxycytidine treatment (Figure 1). We investigated MMP expression in HLA-G negative human leukemia cell 
lines and their HLA-G positive counterparts by sqRT-PCR. Figure 3 reveals that most of the examined MMPs were up-regulated following AZA-treatment of cell lines MT1, JURKAT and RAJI. Similar results were obtained with other AZA-treated cells, including U937, JY and RAMOS (data not shown). In contrast, the expression profile of all investigated MMPs was unchanged in the AZA-treated JAR choriocarcinoma cell line (JAR +AZA).

Analysis of MMP expression in HLA-G transfectants. Figure 3 indicates that AZA-treatment of leukemia cell lines activates not only HLA-G transcription but also that of some MMPs. We were unable to distinguish whether up-regulation of some MMPs was generated by HLA-G expression or by AZA-treatment alone. Therefore, to examine the sole effect of HLA-G on MMP transcription, we used HLA-G transfectants (.221-G1, K562-G1, K562-G2). Figure 4 depicts that the MMP profiles in parental cell lines 221 and K562 were unchanged following HLA-G1 or -G2 expression in HLA-G transfectants. On the other hand, many MMPs were up-regulated after AZA-treatment. These included MMP's 2, 13 and 17 in 221+AZA and MMP's 2, 9, 10, 12, 16, and 20 in K562+AZA.

Expression of TIMP transcripts in choriocarcinoma and leukemia cell lines. Matrix metalloproteinases are inhibited by specific endogenous tissue inhibitors of metalloproteinases (TIMPs), which comprise a family of four protease inhibitors: TIMP1, TIMP2, TIMP3 and TIMP4. Using sqRT-PCR, we analyzed the transcription of TIMPs (TIMP1-TIMP4) in association with HLA-G expression in choriocarcinoma and leukemia cell lines. HLA-G negative cell lines were converted to their HLA-G positive counterparts using AZA-treatment or by HLA-G transfection; with JEG-3 cells as the HLA-G positive control. Figure 5 depicts that HLA-G expression of 221-G1, K562-G1, K562-G2 transfectants had no effect on TIMPs transcription. Increased levels of some TIMPs were observed in cell lines following DNA hypomethylation with AZA reagent. These included TIMP1 in RAJI+AZA; TIMP2 in RAJI+AZA, .221+AZA and K562+AZA; TIMP3 in JAR+AZA, MT1+AZA, RAJI+AZA, .221+AZA and K562+AZA; TIMP4 in JURKAT+AZA and RAJI+AZA. These results provided the conclusion that there is no HLA-G expression responsible for TIMP transcription up-regulation; only epigenetic modulation of the TIMP genes.

\section{Discussion}

The role of HLA-G in human pregnancy has been intensely studied in recent years. It was demonstrated that a specific subset of placental trophoblasts, so called extravillous cytotrophoblasts (evCT), invade the maternal decidua during the first trimester of gestation. The invading trophoblasts undergo striking and rapid changes in cellular functions that are strictly regulated in time and space. The invasive capacity of evCT is highest during the first trimester of gestation and it correlates with high levels of HLA-G molecules [5,7]. It has

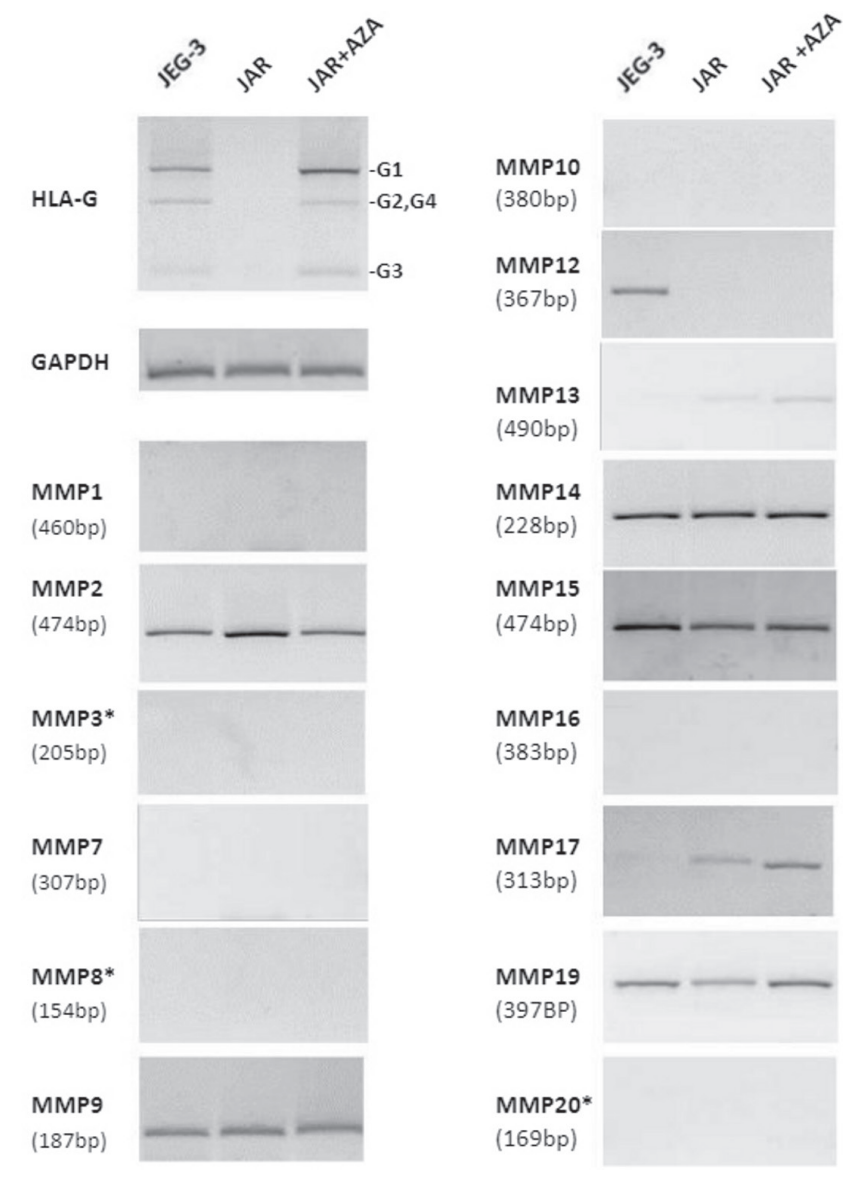

Figure 2. Expression of MMPs in choriocarcinoma cell lines JEG-3 and JAR. HLA-G and MMP expression in JAR cells following AZA-treatment. HLA-G and MMP transcripts were investigated by sqRT-PCR in cell lines: JEG-3 (HLA-G positive), JAR (HLA-G negative) and JAR treated with AZA (HLA-G positive). The following set of MMPs was analyzed: MMP-1, -2, -3, -7, -8, -9, -10,-12,-13,-14, -15, -16, -17,-19, -20. GAPDH: endogenous control. HLA-G isoforms: -G1, -G2, -G3, -G4.

Table 3. Primers and probes used for HLA-G analysis by qRT-PCR.

\begin{tabular}{|c|c|}
\hline Name & Sequence \\
\hline HLA-G-F & 5'-CTGGTTGTCCTTGCAGCTGTAG-3‘ \\
\hline HLA-G-R & 5'-CCTTTTCAATCTGAGCTCTTCTTTCT-3` \\
\hline HLA-G probe & 5`CACTGGAGCTGCGGTCGCTGCT-3` \\
\hline GAPDH-F & 5`CATGGGTGTGAACCATGAGAA-3` \\
\hline GAPDH-R & 5'-GGTCATGAGTCCTTCCACGAT-3' \\
\hline GAPDH probe & 5'-AACAGCCTCAAGATCATCAGCAATGCCT-3‘ \\
\hline
\end{tabular}

also been confirmed that trophoblast invasion is dependent on the function of various MMPs able to degrade extracellular matrix (ECM) components present in the decidua. MMP inhibitors are also implicated in trophoblast invasion because unrestricted invasion is associated with pre-malignancy and malignant choriocarcinoma. Tumor invasion and trophoblastic invasion share many similar mediators. In 


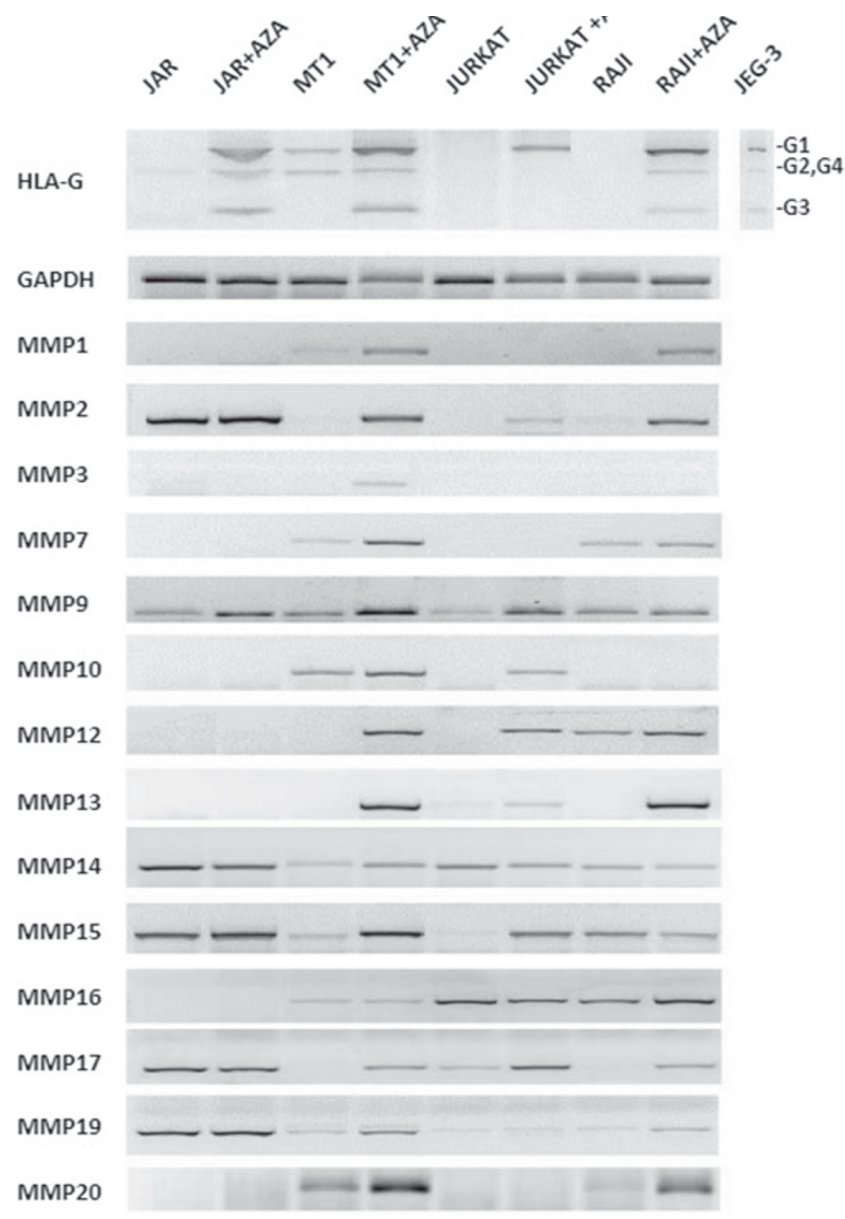

Figure 3. Expression of HLA-G and MMPs in leukemia cell lines before and after AZA-treatment. HLA-G and MMP transcripts were examined by sqRT-PCR in leukemia cell lines (MT1, JURKAT and RAJI) and in their AZA-treated counterparts (MT1+AZA, JURKAT+AZA and RAJI+AZA). JAR cells were used as HLA-G negative control. Cells JAR+AZA and JEG3 were used as HLA-G positive controls. The following set of MMPs was explored: MMP-1, $-2,-3,-7,-9,-10,-12,-13,-14,-15,-16,-17,-19,-20$. GAPDH: endogenous control. HLA-G isoforms: -G1, -G2, -G3, -G4.

addition, Hiden et al. [35] recently compared MMP expression in trophoblasts from first trimester placenta (representing an invasive, mostly HLA-G positive phenotype) and they also assessed MMP expression in trophoblasts from full-term placenta. They identified proteases expressed in invasive trophoblasts that degrade the ECM components present in the decidua and they further identified MMP12 as the protease with the highest expression levels in isolated first trimester trophoblasts [35].

Herein, we examined the relationship between HLA-G and MMP transcription with JAR and JEG-3 choriocarcinoma cell lines. Both cell lines were generated from gestational choriocarcinoma. The JEG-3 cell line was established from the cerebral metastasis of a choriocarcinoma and subsequently cultured for hundreds of passages in hamster cheek- pouches and also in tissue cultures. While JAR and JEG-3 are frequently applied as models for in vitro studies of trophoblasts, the JAR cells do not express HLA class molecules but JEG-3 express HLA-G, HLA-E and HLA-C [36]. Therefore, in terms of HLA expression, JAR cells resemble villous trophoblast, while JEG-3 are extravillous cytotrophoblasts.

We demonstrated that JAR cells (HLA-G negative) and JEG-3 (HLA-G positive) express a similar panel of examined MMPs; except for the MMP12 metalloproteinase. Transcripts of MMP12 metalloelastase were detected only in HLA-G positive JEG-3 cells and not in HLA-G deficient JAR cells. This is supported by Hiden et al. [35] who identified MMP12 as a proteolytic enzyme highly expressed in primary trophoblasts isolated from first trimester placenta.

Our results are also supported by Grummer et al. [37] who investigated the invasion of JAR and JEG-3 cells in the

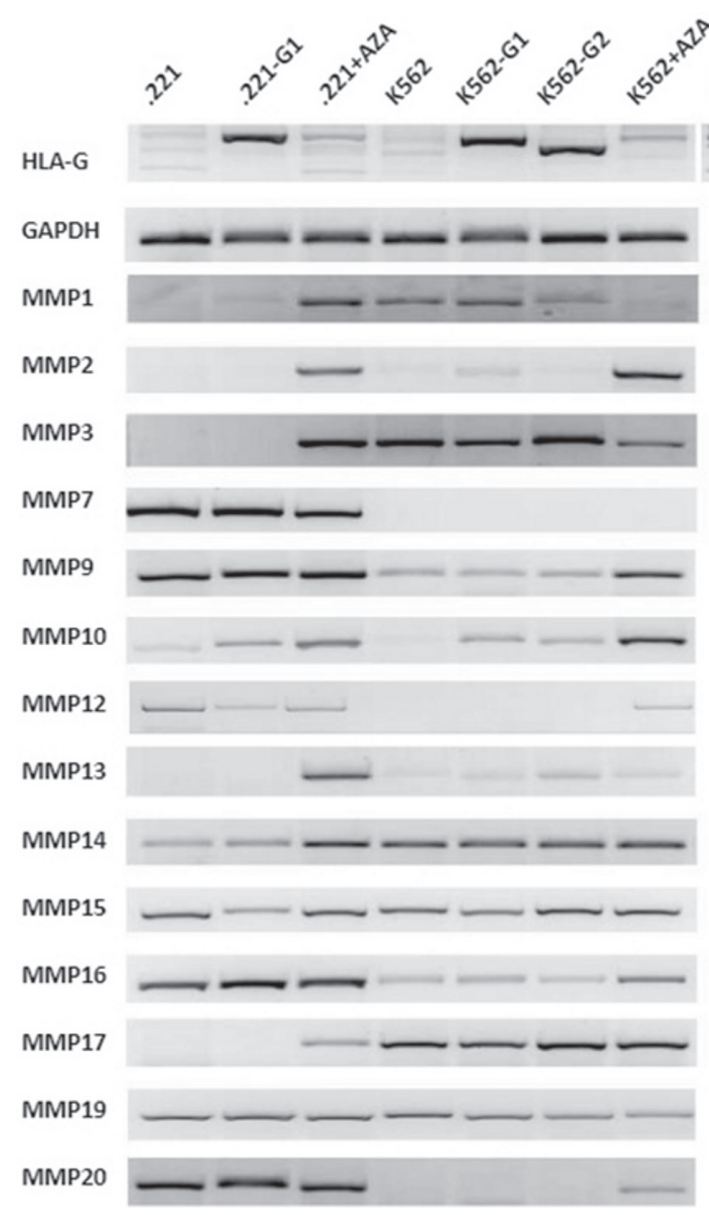

Figure 4. Expression of MMPs in HLA-G transfectants of leukemia cell lines. HLA-G and MMP transcripts were examined by sqRT-PCR in HLA-G negative cell lines (.221 and K562), in HLA-G positive transfectants (.221-G1, K562-G1, K562-G2) and in AZA-treated cells (.221+AZA, $\mathrm{K} 562+\mathrm{AZA})$. Choriocarcinoma cell line JEG-3 was used as HLA-G positive control. The following panel of MMPs was analyzed: MMP-1, $-2,-3$, $-7,-9,-10,-12,-13,-14,-15,-16,-17,-19,-20$. GAPDH: endogenous control. HLA-G isoforms: -G1, -G2,-G3, -G4. 


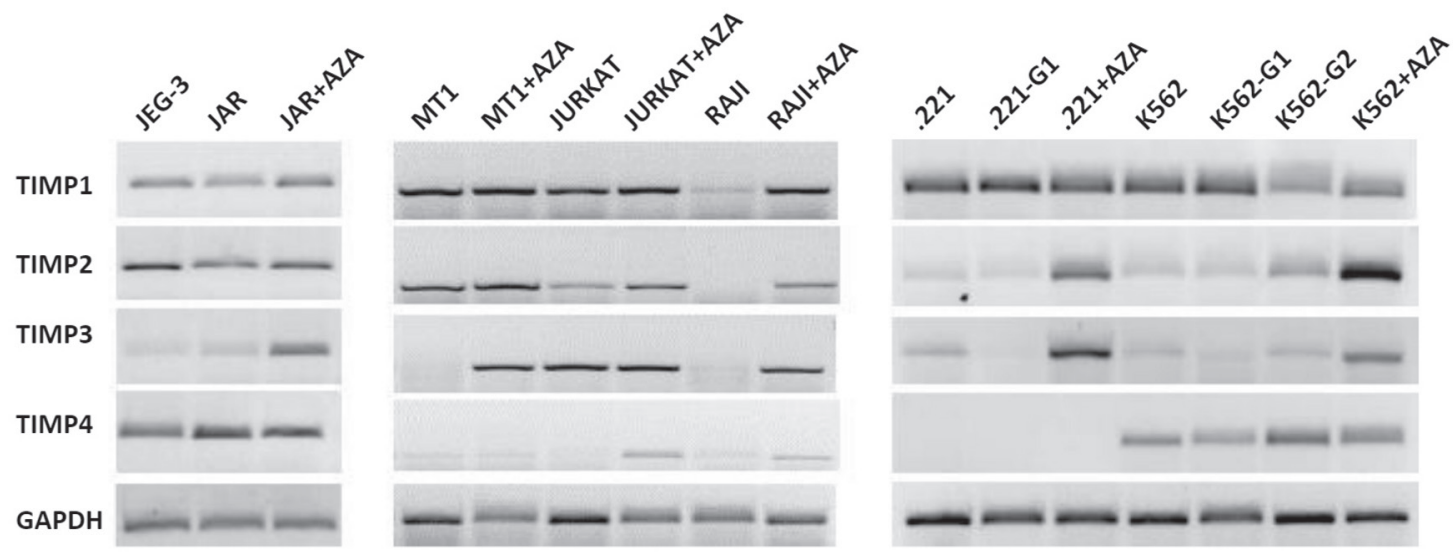

Figure 5. TIMP expression in choriocarcinoma and leukemia cell lines. TIMP1-4 transcripts expressed in choriocarcinoma and leukemia cell lines were examined using sqRT-PCR. HLA-G negative cell lines were converted to their HLA-G positive counterparts by AZA-treatment or HLA-G transfection. JEG-3 cells were used as HLA-G positive control and GAPDH as endogenous control.

human endometrium. These authors demonstrated that in contrast to JAR cells, JEG-3 spheroids had higher invasion in underlying endometrial stroma [37]. It has also been demonstrated that MMP12 expression in some cancers correlates with tumor invasion and metastasis, where MMP12 was highly expressed in non-small cell lung cancer, gastric cancer and cutaneous melanoma, and it was also strongly associated with tumor spread [38-40].

Aberrant HLA-G expression has been detected in various malignancies and is often linked with tumor invasion and metastasis $[8,10,19]$. It is established that many tumors have increased levels of matrix metalloproteinases involved in tumor progression [31,34], and recently observed that engineered expression of HLA-G molecules in the HO-8910 ovarian cancer cell line subsequently induced transcription of MMP15 metalloproteinase [18]. Similarly, strong correlation between HLA-G and MMP15 expression was demonstrated in primary ovarian cancer lesions.

It was proposed that up-regulation of some MMPs could be linked with HLA-G expression, and therefore we analyzed MMP transcription in association with HLA-G expression using human choriocarcinoma and leukemia cell lines. We investigated the effect of HLA-G expression on MMP induction in JAR cells and demonstrated that JAR cells expressed HLA-G proteins after AZA-treatment but no change in MMP transcription was detected (neither MMP12 nor MMP15 transcription was influenced). We then evaluated MMP transcription in association with HLA-G expression using various HLA-G negative leukemia cell lines and their HLA-G expressing counterparts (prepared by AZA-treatment or by HLA-G transfection). We demonstrated that the levels of MMP mRNAs in K562 and .221 cell lines were not affected by HLA-G expression in transfectants .221-G1, K562-GI and K562-G2. However, treatment of leukemia cells with AZA reagent resulted not only in up-regulation of HLA-G expression, but also in transcription of some MMPs. We assume that this MMP transcription was caused by epigenetic modulation of MMP genes following AZA-treatment; and not solely by HLA-G expression. Subsequent sqRT-PCR analysis of TIMP1-TIMP4 transciption associatiated with HLA-G expression in choriocarcinoma and leukemia cell lines confirmed that HLA-G expression in the .221-G1, K562-G1 and K562-G2 transfectants had no effect on TIMPs transcription; but we established increased levels of some TIMPs following AZA-treatment.

Finally, our combined results determined that HLA-G expression induction had no effect on MMP and TIMP transcription in the cell lines used in this study. The difference in MMP12 expression observed between JEG-3 and JAR cells is therefore explained by the high invasion potential of the JEG-3 cells.

Acknowledgements: This work was supported by VEGA grant number 2/0080/15 awarded by Scientific Grant Agency of Ministry of Education of Slovak Republic and by Slovak Academy of Sciences.

\section{References}

[1] CAROSELLA ED, FAVIER B, ROUAS-FREISS N, MOREAU $\mathrm{P}$, LEMAOULT J. Beyond the increasing complexity of the immunomodulatory HLA-G molecule. Blood 2008; 111: 4862-4870. https://doi.org/10.1182/blood-2007-12-127662

[2] CURIGLIANO G, CRISCITIELLO C, GELAO L, GOLDHIRSCH A. Molecular pathways: human leukocyte antigen G (HLA-G). Clin Cancer Res 2013; 19: 5564-5571. https:// doi.org/10.1158/1078-0432.CCR-12-3697

[3] ALEGRE E, RIZZO R, BORTOLOTTI D, FERNANDEZLANDÁZURI S, FAINARDI E et al. Some basic aspects of HLA-G biology. J Immunol Res 2014; 2014: 657625. https:// doi.org/10.1155/2014/657625

[4] CAROSELLA ED, ROUAS-FREISS N, TRONIK-LE ROUX D, MOREAU P, LEMAOULT J. HLA-G: an immune checkpoint molecule. Adv Immunol 2015; 127: 33-144. https:// doi.org/10.1016/bs.ai.2015.04.001 
[5] LE BOUTEILLER P. HLA-G in human early pregnancy: control of uterine immune cell activation and likely vascular remodeling. Biomed J 2015; 38: 32-38. https://doi. org/10.4103/2319-4170.131376

[6] FERREIRA LMR, MEISSNER TB, TILBURGS T, STROMINGER JL. HLA-G: At the interface of maternalfetal tolerance. Trends Immunol 2017; 38: 272-286. https:// doi.org/10.1016/j.it.2017.01.009

[7] PERSSON G, MELSTED WN, NILSSON LL, HVIID TVF. HLA class Ib in pregnancy and pregnancy-related disorders. Immunogenetics 2017; 69: 581-595. https://doi.org/10.1007/ s00251-017-0988-4

[8] ROUAS-FREISS N, MOREAU P, FERRONE S, CAROSELLA ED. HLA-G proteins in cancer: do they provide tumor cells with an escape mechanisms? Cancer Res 2005; 65: 10139-10144. https://doi.org/10.1158/0008-5472.CAN-050097

[9] AMIOT L, FERRONE S, GROSSE-WILDE H, SELIGER B. Biology of HLA-G in cancer: a candidate molecule for therapeutic intervention? Cell Mol Life Sci 2011; 68: 417-431. https://doi.org/10.1007/s00018-010-0583-4

[10] ZIDI I, BEN AMOR N. HLA-G regulators in cancer medicine: an outline of key requirements. Tumor Biol 2011; 32: 1071-1086. https://doi.org/10.1007/s13277-011-0213-2

[11] BORTOLOTTI D, GENTILI V, ROTOLA A, CASSAI E, RIZZO R. Impact of HLA-G analysis in prevention, diagnosis and treatment of pathological conditions. World J Methodol 2014; 4: 11-25. https://doi.org/10.5662/wjm.v4.i1.11

[12] AMIOT L, VU N, SAMSON M. Immunomodulatory properties of HLA-G in infectious diseases. J Immunol Res 2014; 2014: 298569. https://doi.org/10.1155/2014/298569

[13] MORANDI F, RIZZO R, FAINARDI E, ROUAS-FREISS $\mathrm{N}$, PISTOIA V. Recent advances in our understanding of HLA-G biology: lessons from a wide spectrum of human diseases. J Immunol Res 2016; 2016: 4326495. https://doi. org/10.1155/2016/4326495

[14] PARK GM, LEE S, PARK B, KIM E, SHIN J et al. Soluble HLA-G generated by proteolytic shedding inhibits NK-mediated cell lysis. Biochem Biophys Res Commun 2004; 313: 606-611.

[15] DONG Y, LIESKOVSKA J, KEDRIN D, PORCELLI S, MANDELBOIM O et al. Soluble nonclassical HLA generated by the metalloproteinase pathway. Hum Immunol 2003; 64: 802-810. https://doi.org/10.1016/S0198-8859(03)00093-4

[16] RIZZO R, TRENTINI A, BORTOLOTTI D, MANFRINATO MC, ROTOLA A et al. Matrix metalloproteinase-2 (MMP-2) generates soluble HLA-G1 by cell surface proteolytic shedding. Mol Cell Biochem 2013; 381: 243-255. https://doi.org/10.1007/s11010-013-1708-5

[17] SHEU JJ, SHIH IEM. Clinical and biological significance of HLA-G expression in ovarian cancer. Semin Cancer Biol 2007; 17: 436-443. https://doi.org/10.1016/j.semcancer.2007.06.012

[18] LIN A, XU HH, XU DP, ZHANG X, WANG Q et al. Multiple steps of HLA-G in ovarian carcinoma metastasis: alter NK cytotoxicity and induce matrix metalloproteinase-15 (MMP-15) expression. Hum Immunol 2013; 74: 439-446. https://doi.org/10.1016/j.humimm.2012.11.021
[19] LIN A, ZHANG X, XU HH, XU DP, RUAN YY et al. HLA-G expression is associated with metastasis and poor survival in the $\mathrm{Balb} / \mathrm{c}$ nu/nu murine tumor model with ovarian cancer. Int J Cancer 2012; 131: 150-157. https://doi.org/10.1002/ ijc. 26375

[20] LIN A, YAN WH. Human leukocyte antigen-G (HLA-G) expression in cancers: roles in immune evasion, metastasis and target for therapy. Mol Med 2015; 21: 782-791. https://doi. org/10.2119/molmed.2015.00083

[21] SOMERVILLE RP, OBLANDER SA, APTE SS. Matrix metalloproteinases: old dogs with new tricks. Genome Biol 2003; 4: 216.1-216.11. https://doi.org/10.1186/gb-2003-4-6-216

[22] HEMMANN S, GRAF J, RODERFELD M, ROEB E. Expression of MMPs and TIMPs in liver fibrosis - a systematic review with special emphasis on anti-fibrotic strategies. J Hepatology 2007; 46: 955-975. https://doi.org/10.1016/j. jhep.2007.02.003

[23] ROY R, YANG J, MOSES MA. Matrix metalloproteinases as novel biomarkers and potential therapeutic targets in human cancer. J Clin Oncol 2009; 27: 5287-5297. https://doi. org/10.1200/JCO.2009.23.5556

[24] HUA H, LI M, LUO T, YIN Y, JIANG Y. Matrix metalloproteinases in tumorigenesis: an evolving paradigm. Cell Mol Life Sci 2011; 68: 3853-3868. https://doi.org/10.1007/ s00018-011-0763-X

[25] HADLER-OLSEN E, WINBERG JO, UHLIN-HANSEN L. Matrix metalloproteinases in cancer: their value as diagnostic and prognostic markers and therapeutic targets. Tumor Biol 2013; 34: 2041-2051. https://doi.org/10.1007/s13277013-0842-8

[26] KHALID A, JAVAID MA. Matrix metalloproteinases: new targets in cancer therapy. J Cancer Sci Ther 2016; 8: 143-153. https://doi.org/10.4172/1948-5956.1000406

[27] POLAKOVA K, BANDZUCHOVA E, TIRPAKOVA J, RUSS G. Modulation of HLA-G expression. Neoplasma 2007; 54: 455-462.

[28] POLAKOVA K, BANDZUCHOVA E, KUBA D, RUSS G. Demethylating agent 5-aza-2_-deoxycytidine activates HLA-G expression in human leukemia cell lines. Leukemia Res 2009; 33: 518-524. https://doi.org/10.1016/j.leukres.2008.08.003

[29] PAUL P, ROUAS-FREISS N, MOREAU P, CABESTRE FA, MENIER C et al. HLA-G, -E, -F preworkshop: Tools and protocols for analysis of non-classical class I genes transcription and protein expression. Human Immunol 2000; 61: 1177-1195.

[30] MOREAU P, MOUILLOT G, ROUSSEAU P, MARCOU C, DAUSSET J et al. HLA-G gene repression is reversed by demethylation. Proc Natl Acad Sci U S A 2003; 100: 1191-1196. https://doi.org/10.1073/pnas.0337539100

[31] ASANO T, TADA M, CHENG S, TAKEMOTO N, KURAMAE T et al. Prognostic values of matrix metalloproteinase family expression in human colorectal carcinoma. J Surgical Res 2008; 146: 32-42. https://doi.org/10.1016/j. jss.2007.02.011

[32] HOST L, PAYE A, DETRY B, BLACHER S, MUNAUT C et al. The proteolytic activity of MT4-MMP is required for its pro-angiogenic and pro-metastatic promoting effects. Int J Cancer 2012; 131: 1537-1548. https://doi.org/10.1002/ ijc. 27436 
[33] HUNAKOVA L, SEDLAKOVA O, CHOLUJOVA D, GRONESOVA P, DURAJ J et al. Modulation of markers associated with aggressive phenotype in MDA-MB-231 breast carcinoma cells by sulforaphane. Neoplasma 2009; 56 : 548556.

[34] KOHRMANN A, KAMMERER U, KAPP M, DIETL J, ANACKER J. Expression of matrix metalloproteinases (MMPs) in primary human breast cancer and breast cancer cell lines: New findings and review of the literature. BMC Cancer 2009; 9: 188-208. https://doi.org/10.1186/14712407-9-188

[35] APPS R, MURPHY SP, FERNANDO R, GARDNER L, AHAD $\mathrm{T}$ et al. Human leucocyte antigen (HLA) expression of primary trophoblast cells and placental cell lines, determined using single antigen beads to characterize allotype specificities of anti-HLA antibodies. Immunology 2009; 127, 26-39. https://doi.org/10.1111/j.1365-2567.2008.03019.x

[36] HIDEN U, EYTH CP, MAJALI-MARTINEZ A, DESOYE G, TAM-AMERSDORFER $C$ et al. Expression of matrix metalloproteinase 12 is highly specific for non-proliferating invasive trophoblasts in the first trimester and temporally regulated by oxygen-dependent mechanisms including HIF-1A. Histochem Cell Biol 2018; 149: 31-42. https://doi. org/10.1007/s00418-017-1608-y
[37] GRUMMER R, HOHN HP, MAREEL MM, DENKER HW. Adhesion and invasion of three human choriocarcinoma cell lines into human endometrium in a three-dimensional organ culture system. Placenta 1994; 15: 411-429.

[38] ZHANG Z, ZHU S, YANG Y, MA X, GUO S. Matrix metalloproteinase-12 expression is increased in cutaneous melanoma and associated with tumor aggressiveness. Tumor Biol 2015; 36: 8593-8600. https://doi.org/10.1007/s13277-0153622-9

[39] GORRIN-RIVAS MJ, ARII S, FURUTANI M, HARADA T, MIZUMOTO M et al. Expression of human macrophage metalloelastase gene in hepatocellular carcinoma: correlation with angiostatin generation and its clinical significance. Hepatology 1998; 28: 986-993. https://doi.org/10.1002/ hep. 510280413

[40] YANG W, ARII S, GORRIN-RIVAS MJ, MORI A, ONODERA $\mathrm{H}$ et al. Human macrophage metalloelastase gene expression in colorectal carcinoma and its clinicopathologic significance. Cancer 2001; 91: 1277-1283. 